\title{
Symbolic crusades in Lusatia and Brittany? An analysis of minority language movements from the perspective of status politics
}

\section{Introduction}

T

his article proposes to examine collective action of organizations promoting minority and regional languages through the prism of status politics. The two following terms will be used here, insofar as they are official expressions in the two countries in focus: the term "minority languages" (Minderheitensprachen) is in official use in Germany, and "regional languages" (langues régionales) - in France. This difference is not accidental, since it reveals how the two states view languages spoken on their "peripheries" (Lipset \& Rokkan, 1967).

In his Symbolic Crusades (first published in 1963), the American sociologist of the Chicago School Joseph R. Gusfield introduced a new perspective on the study of "moral" movements such as the American temperance movement. The main contribution of his approach is the distance it takes from the presumed moral motivations of mobilized groups. Those moral values are considered a tool in the struggle for status and social prestige that motivated such mobilization. Indeed, the author invites us to discard our pre-notions in order to read issues of (non-)drinking as symbols of membership in status groups, defined here as cultural and social groups united by the anxiety of losing their status. First proposed in Symbolic Crusades, 
the categories of status groups, status politics, symbolic crusades and moral crusades have been applied in further studies (Broqua, 2015; Mathieu, 2005; Traïni, 2011).

It thus seems relevant to analyse collective action for regional and minority languages in Lusatia and Brittany in the light of "status politics" (Gusfield, 1963, 1986), in order to determine whether or not it constitutes symbolic crusades in the sociological sense. Status politics is an expression of a political conflict over the allocation of social prestige, in this case - as far as languages are concerned. The allocation of prestige can be influenced by status movements engaged in "symbolic crusades" as understood above. The label of status politics particularly applies to qualitative movements rather than to instrumental and quantitative ones, even if so-called qualitative mobilizations can integrate instrumental goals (for instance the implementation of public policies). Moreover, it is a heuristic approach to search for the qualitative part of every social movement (Mathieu, 2005), even movements which seem mainly quantitative at first sight.

In the 1980s, the theory of New Social Movements (NSMs) appeared in social sciences to explain mobilizations shaped by group identities or quality of life issues such as feminism, ecology or regionalism. For researchers like the French sociologist Alain Touraine (Touraine, 1978), the 1960s and 1970s were characterized by these mobilizations of a new kind, breaking with traditional materialistic demands in the so-called post-industrial society (Touraine, 1978). Regionalist mobilizations enhancing territorial and cultural specificities, such as the presence of regional and minority languages, have often been viewed in terms of this pattern. Considering that the relevance of the NSMs theory has long been debated in scholarship (Neveu, 2011), I will only retain from it the idea that certain social movements integrate a symbolic aspect, which is less emphasized in other mobilizations. It might then enrich this discussion to think about minority languages as symbols of belonging in status groups, in order to better understand participation and commitment to linguistic causes.

A common paradigm in contemporary social sciences is to assume that global society is characterized by an increased social and spatial mobility (Urry, 2005), which results in the break-up of traditional speech communities as well as religious ones' (Gauchet, 1985). This process of individualization results in a change of reference point for social actors, who tend to detach themselves from the groups among which they grow up and to cultivate

\footnotetext{
${ }^{1}$ The latter assumption is relevant in the two Sorbian cases selected for this study, and most of all - in the Upper Sorbian one.
} 
their own singularity (Le Bart, 2008). Therefore, speaking a minority language today is more an individual choice than social obviousness. As explained by the Polish sociolinguist Nicole Dołowy-Rybińska, regional and minority language newspeakers express a will of commitment that is further experienced through participation in communities of practice (Dołowy-Rybińska, 2016b). Moreover, as shown by James Costa, the use of language as a mobilizing category reflects broader social processes in which languages are only an element among others (Costa, 2013).

I make an attempt to differentiate my perspective from regular sociolinguistic approaches which are more usual for such research. Even if notions of critical sociolinguistics are used here to analyse the material, this study is mostly inscribed in the field of political sociology. Within the latter, the notion of symbolic crusade is quite frequently employed to describe a multitude of social movements, and certainly has no link with the original historical crusades undertaken in the Middle Ages. What is more, one should not lose sight that even the historical example of the temperance movement chosen by Gusfield was an illustration among others that he picked to develop his notion. This article draws on previous applications of the concept in political sociology in order to examine its potential for the description of collective action for regional and minority languages. Let me also clearly assert that by doing so I do not intend to hamper the revitalization efforts made by members of the four language communities in question. Besides, my article does not examine whether efforts made by the activists I met are effective or not. ${ }^{2}$

\section{Fieldwork studies}

Brittany and Lusatia, the two regional territories where fieldwork was conducted from January 2017 to June 2019, are both linguistically subdivided and each of them harbours two linguistic minorities, even though linguistic claims in the same region may sometimes overlap. In effect, this study focuses on the cases of mobilizations for Breton and Gallo in Brittany, and mobilizations for Upper Sorbian and Lower Sorbian in Lusatia. Brittany and Lusatia also share a strong rural tradition. Brittany is known for having long been a cradle of Catholicism, especially in the Lower Breton departments of Finistère and Morbihan, and the main part of Upper Lusatia is a Catholic enclave in a Protestant country. Although Brittany

\footnotetext{
${ }^{2}$ Indeed, my perspective will not be driven by normative questions, but by a constant search for axiological neutrality as theorized by Max Weber (Weber, 1919).
} 
and Lusatia experienced massive Francisation and Germanisation policies in the nineteenth and twentieth centuries, not all linguistic minorities considered here have suffered equally. For instance, Lower Sorbian was more affected than Upper Sorbian. The four cases of this comparison offer a way to explore the diversity of their positioning on the scale of symbolic crusades. Indeed, although they can be placed on a continuum of politicization, the cases of Breton, Gallo, Upper Sorbian and Lower Sorbian do not necessarily cover the same social, cultural and political functions.

According to a survey conducted in 2018, there are 207,000 Breton speakers and 191,000 Gallo speakers in Brittany (TMO Régions, 2018). The two regional languages are taken into account by official regional public institutions (Kernalegenn, 2018), although Gallo is less visible than Breton. Indeed, the latter has longer been institutionalized and treated as a political issue by ethno-regionalist parties. Gallo campaigners tend to attach a greater importance to a traditional cultural repertoire preserved in the rural practices of Upper Brittany. Lusatia, in turn, which is not an official territory, but first and foremost a cultural and historical region, is divided between the Länder of Saxony and Brandenburg. Considered one national minority, Lusatian Sorbs are divided into the Upper Sorbs, speaking Upper Sorbian (between 12,000 and 15,000 speakers) and the Lower Sorbs, speaking Lower Sorbian (between 5,000 and 6,000 speakers, DołowyRybińska, 2016b). In the two Länder, they have access to cultural and political institutions and funding schemes. However, above all in Lower Lusatia, language transmission suffers from a decreasing number of Sorbian-speaking families, and bilingual schools do not manage to replace these socialization forces (Dołowy-Rybińska \& Ratajczak, 2019). In Upper Lusatia, Catholicism plays a main role in the maintenance and tightening of the minority speech community, a role that the Protestant religion does not perform in such an intensive way in Lower Lusatia.

Fieldwork was conducted in both regions: Brittany and Lusatia. The first stage was a series of ten semi-structured interviews with five Upper Sorbian campaigners, four Lower Sorbian activists, and a non-Sorbian federal deputy of Brandenburg involved in Lower Sorbian issues. This stage also included several participatory observations in different situations, such as informal and formal meetings, and a session of the Sorbian Council in Brandenburg. The same technique was then applied to the field of Breton, for instance following a running event called Redadeg, organized every couple of years in Brittany to raise funds for immersion schools and other projects promoting Breton, and 
sometimes also Gallo. Further interviews were conducted in Lusatia during the spring of 2018 (three with Upper Sorbian campaigners, one with a Lower Sorbian activist); these were combined with a deeper integration of the researcher in the Sorbian cultural and religious life. Back in Brittany, a series of seven interviews with Gallo speakers willing to defend their language and six with Breton activists was conducted, as well as further observations in different contexts (such as a Gallo lesson in a primary school, an assembly of a Gallo institution, a meeting of different Breton associations, demonstrations, actions of civil disobedience).

The semi-structured interviews were divided into three parts. First, the interviewees answered information questions about the organization they belonged to (when it had been established, what were its particular features, what stance it took on the defence of the language). Then, the questions concerned the place of the informant in the organization and his/her motivations to engage in the promotion of the endangered language(s) in focus. His/her relation to the regional or minority language was hence explored. The third part of the interview focused on biographical markers: primary socialization, school and professional career, and social and linguistic trajectories were examined in detail. Of course, the interviewees were told at the beginning of the process that they could answer freely, refuse to answer, and add some details or information that the researcher had not thought of before. Moreover, the interviews with activists were used as an opportunity for observation (such as paying attention to the activists' ways of living). I also had an opportunity for informative conversations during my observations; I talked to regional or minority speech campaigners, who could provide contextual information.

\section{Social status movements}

Before considering the limits of their designation as "symbolic crusades", I will first explore the status elements of linguistic movements for Gallo and Breton in Brittany, and for Upper Sorbian and Lower Sorbian in Lusatia. Indeed, collective action in these four cases involves issues of social status, but should not be reduced to them.

One important contribution of Gusfield's study of the temperance movement has been a departure from a vision of history only driven by economic aspects. In fact, he insisted on the symbolic significance of such movements by defining them as "one way through which a cultural group acts to preserve, defend, or enhance the dominance and prestige of 
its own style of living within the global society" (Gusfield, 1986, p. 3). Applying his observation to collective action for regional and minority languages means that it is necessary not only to consider the linguistic interest of the promotion of regional and minority language, but also to put emphasis on the specific visions of the social world that this particular kind of collective action carries.

First, I will explore the different ways Breton, Gallo, Upper Sorbian and Lower Sorbian speech communities perceive the territorial scales they are embedded in, and how they sometimes use globalization issues to short-circuit European nation-states. Being part of a speech community implies being able to draw its boundaries. In that respect, claiming a territorial belonging and a "local" culture like Breton and Sorb also requires them to position themselves toward the scale of the state, be it considered "national" or not. As a matter of fact, the relations between centre and periphery (Lipset \& Rokkan, 1967) differ from country to country. Although Germany and France are geographically close, the former is a federal state, whereas the latter is characterized by a high degree of centralization. While a federal secretary dedicated to four "national" minorities (Sorbs, Danes, Sinti and Roma, Frisians) exists in Germany, the French Constitution insists that French is the language of the Republic (Article 2 provides: "the language of the Republic is French"), and does not recognize any national minority (which was the main reason invoked for the non-ratification of the European Charter for Regional or Minority Languages).

Although the interviewees defend a certain identification with the regional community - encompassing different meanings in Brittany and in Lusatia - they face a process of homogenization and "nationalization" 3 of society in their respective regions. To keep up with the previous analogy, when Gusfield wrote his study on the temperance movement he remarked that the figures of the drinker and the abstainer were actually symbols of two different visions of society. The power balance was, however, in favour of "modern" society, represented by the drinker, taking into account that "the localistic culture clings to the traditional while the easier, relaxed, modern ways are the province of the national culture. It is this national culture which becomes the more prestigeful and powerful as America becomes more homogenous" (Gusfield, 1986, p. 10). To some extent, minority speech communities are confronted with the same process. Today, young Bretons and Sorbs attend the same schools and universities as non-speakers, where they come

\footnotetext{
3 "Nationalization" will be used here to define the scale of the state, in Gusfield's understanding, although I am aware that it is not perceived as a nation by members of the status groups under study.
} 
to realize that their community culture is a minority one (which can be a biographical turning point). A young association activist for Gallo, whose job is to collect variations of the language in different towns of Upper Brittany, tells for instance that when she left Brittany to study in another region of France she realized that her French was heavily influenced by Gallo expressions:

And even at one moment - I can remember the turn of phrase - it was funny because in fact in Gallo 'terjou', well, 'toujours' (always), means 'at any rate'. And so after an oral exam I say : 'Well, here we are, exams are over, always!'. And the girls actually didn't understand; they say: 'Always?', and I say 'Well, yes, always', I say, 'that's what we say at home'. But it actually was a Gallo turn of phrase. And that's when you realize, when you go to another place, that your speech is different. ${ }^{4}$

Furthermore, the interviewees often regarded the "national status system" (Gusfield, 1986, p. 141) with suspicion or mistrust. This is apparent in the following extracts. The first one comes from an interview with an Upper Sorbian activist with high responsibilities in the umbrella organization Domowina ("home" in Upper and Lower Sorbian), and the second one - with a young activist fighting for the Breton and Gallo languages in various structures, but most importantly in the student organization called Kejadenn (Meeting):

So it implies many framework elements or instruments that we really have to set in place. The state plays a very important role there, and because of this overdominance of German we have to push against this, and the problem is often that a Sorb has to fight for his rights. ${ }^{5}$

Researcher: Do you consider the question of languages a political question? Informant: France makes a political question out of it. ${ }^{6}$

\footnotetext{
4 “Et même à un moment, je me souviens dans une tournure de phrase, c'était drôle parce qu'en fait en gallo, 'terjou', enfin 'toujours', il veut dire 'en tout cas'. Et en fait, après avoir passé un oral, je dis : 'ah bah ça y est, les examens sont finis, toujours!'. Et en fait les filles, elles n'ont pas compris, elles disent 'toujours?'. Je dis 'bah oui, toujours', je dis, 'nous on dit ça chez nous'. Mais les examens sont finis, toujours!'. Et en fait les filles, elles n'ont pas compris, elles disent 'toujours?'. Je dis 'bah oui, toujours', je dis, 'nous on dit ça chez nous'. Mais parce que c'était une tournure gallèse, en fait. Mais c'est là que tu te rends compte en fait, quand tu vas ailleurs, de la différence de ton parler." The interview was conducted at her office in Rennes on 9 October 2018. All translations by the author.

5 "Also es bedingt viele Rahmenbedingungen oder viele Instrumente die wir richtig zusammen setzen müssen. Da ist der Staat ein sehr sehr grosser Anteil weil wir eben diesen Überdominanz des Deutschens, da müssen wir gegen drücken und das Problem ist das oft, der Sorbe für sein Recht kämpfen muss...". The interview was conducted in his office in Bautzen on 19 March 2018; the office is located in the Sorbian House, a cultural centre which is home to several Sorbian associations.

6 "Est-ce que tu considères la question des langues comme une question politique? - La France en fait une question politique". The interview was conducted on the premises of a cultural Breton association in Rennes (9 November 2018), where the informant (a young activist for both languages of Brittany) was doing his internship at the time.
} 
The national scale is not the only one to be criticized by minority speech community members. More generally, they develop their own perception of globalization and the globalized world. While the so-called "consumer society" is often seen as a threat owing to its potential to standardize cultures, minority speech activists are aware that globalization also means a strategic opportunity for them to highlight the values of the local scale and the singularity of their own language and cultural practices. A primary private school teacher trying to introduce more Gallo lessons in her class, and member of the administration of a Gallo semi-public structure, tells for instance: "You see, we are in something very universal, very global and stuff, to have this recognition of local richness... the bigger it is, the more we need to cling to something small". ${ }^{7}$ What is perceived as a globalization process is therefore seized by linguistic activists to short-circuit a national scale constructed, at least partially, as a hurdle.

At this point I will turn attention to the (self)-representations of minority speech communities and their campaigners. To promote a language implies to transmit and to spread it, to a certain extent like the temperance movement tried to convert people to non-drinking (Gusfield, 1963, 1986). Although the contexts are very different - since that movement is emblematic of moral crusades, where a group tries to impose its style of life on others, and language revitalization movements happen to counterbalance the endangerment of minority speech communities - the common point is that the status group tries to increase the community: by deterring people from drinking, or by motivating them to learn the minority language of the area they live in. This stake is vital for minority speech campaigners, who would be doomed to see the number of speakers decrease if no effort was made to spur other people to learn the language, be it adult newspeakers or little children within the family.

What is more - and in contrast to what I heard from some Breton activists ${ }^{8}$ - transmitting a language barely comes without the transmission of a cultural background. A detour by the notion of symbolic crusade is thus useful to understand how Breton and Sorbian language campaigners participate in the transmission of cultural and sometimes moral values.

\footnotetext{
7 “Tu vois, on est dans quelque chose de très universel, très mondial, tout ça, d'avoir cette reconnaissance de la richesse locale... plus c'est grand et plus on a besoin de se rattacher à quelque chose de petit". I interviewed this teacher in her classroom in the private school of a small town Bazouges-la-Pérouse (Ille-et-Villaine, Brittany) on 13 November 2018.

${ }^{8}$ This rhetoric is often employed by civil disobedience Breton activists who explain leaving cultural background behind by the need to only focus on language demands.
} 
Indeed, Upper and/or Lower Sorbian traditional celebrations like ptači kwas (Upper Sorbian for "bird wedding") or its Lower Sorbian version ptaškowa swajźba, Zapust (feast night) or Kokot (a cock) are taught in Sorbian schools, with children getting used to wearing traditional Sorbian costumes like the drasta/drastwa (Upper and Lower Sorbian folk dress with several local variations). It is quite common for Sorbs to dress up their children in traditional costumes for official events, from mobilization meetings against the closing of Sorbian classes to patriotic holidays such as the Saxon homeland day. ${ }^{9}$ The same is the case when it comes to the transmission of Gallo in Brittany: although it is taught in special classes for fifteen minutes a day (the Cllâssiers (to teach) methodology), without necessarily highlighting the rural traditional contexts in which the language used to be spoken, its presence in public or half-public spaces is very often connected to a specific cultural repertoire like tale telling or specific kinds of storytelling, e.g. menteries (storytelling contests which consist in telling the audience the most convincing lie) or diries (a simpler kind of storytelling). When asked about the presence of the language on the radio, an activist for Gallo in charge of collecting linguistic material told me that radio podcasts she posted on the website of her organization detailed how Upper Breton peasants used to live in the nineteenth century, with very precise instructions in Gallo on how to make cider or washing powder. This is an indication of the strong attachment of Gallo activism to traditional rural practices that go hand in hand with the language. Considering the fieldwork conducted among Breton language activists, I assume that they put less emphasis on the transmission of rural culture and often claim that they separate the cultural and the linguistic sphere (be it fully possible or not). ${ }^{10}$

Nevertheless, immersive Diwan schools do not function without cultivating a singular vision of the social world. First, their funding channels have an effect on this process. Diwan schools have long had to wait five years from their creation to get financial help from the state. This time has recently been reduced to two years. During this period of self-funding, parents are asked to help organizing cultural and festive events to collect money for their local Diwan school, which means they are encouraged to take responsibility for their sustainability. What is more, each Diwan school is managed by a board of administration composed of parents, socializing them to decision-making and resistant

\footnotetext{
${ }^{9}$ Observation at a parents meeting in a Sorbian Kindergarten in the town of Sielow, conducted on 6 March 2017, and observation in the Sorbian village of Nebelschütz, conducted on 24 March 2018.

${ }^{10}$ This remark on the difficulty of drawing a clear line between language and culture was suggested to me by Professor Erik Neveu, and I would like to thank him here.
} 
attitude. Not only parents, but also pupils develop a sense of belonging to a community which differs from regular French public schools. I met a Breton activist in charge of an audio-visual project about regional and minority languages to whom scholarship in Diwan meant a lot. She described how her group called Kenstroll Breizh (Collective of Brittany) $)^{11}$ had arrived at the UN Forum on Minority Issues in 2017 as follows: "And so we arrived there as cliché Diwan students, you know, with our backpacks; I had just arrived on the coach, so my hiking shoes were hanging at mine; and then with all the others in their suits...".13 This vision of (former) Diwan students (Diwanais) as a group with distinct characteristics - such as left-wing and ecological values (Kernalegenn, 2006), which translated into their appearance, clothing and corporal hexis, contrasted to "all the others", dressed "in suits" - was reported to me several times in the course of my fieldwork, and was also observed by Nicole Dołowy-Rybińska (2016a, p. 288).

This shows that regional and minority speech communities do not only defend particular languages. They also display "styles of life", defined by Gusfield as systems of values, customs and habits distinctive to a status group (Gusfield, 1963, 1986). These styles of life are to be looked at with respect to social history of linguistic movements. For instance, the contemporary Breton engagement is heavily influenced by the renaissance of the Breton political movement in the 1960s and 1970s, characterized by a strong spirit of protest and left-wing ideals (Kernalegenn, 2006). Likewise, one cannot understand the Upper Sorbian movement if one does not consider the Catholic background that is strongly connected to it in Upper Lusatia. "It is clear that we stand for Christian faith, and then also for the Sorbian language ${ }^{\prime \prime}{ }^{14}$ an Upper Sorbian Domowina representative explains.

Moreover, the struggle for prestige is real considering that minority languages suffered from social discrimination in the nineteenth and twentieth centuries. Defending bilingual schools by arguing they will make children more competent and intelligent is then also a way to re-inject prestige in the representations of minority languages. To put it in a nutshell,

\footnotetext{
${ }^{11}$ The group gathered around ten young Breton activists from different (cultural and political) organizations in order to attend the UN Forum on Minority Issues in 2017.

12 The annual UN Forum on Minority Issues invites official or "unofficial" national minorities of UN member states. The main topic varies from year to year; in 2017 the focus was on youth issues.

13 "Et donc on est arrivés vraiment cliché des Diwanais, tu sais, avec nos sacs à dos, moi je venais juste d'arriver en car, du coup j'avais mes chaussures de rando bringuebalantes au sac à dos, et puis avec tous les autres en mode costard-cravate..." The interview was conducted at the informant's home on 17 January 2019.

14 "Das ist klar, dass wir einmal dafür einschätzen, das christlichen Glauben, und zum zweitens auch die sorbische Sprache".
} 
talking about social status movements (Gusfield, 1963, 1986) to qualify the action of minority speech communities in Brittany and Lusatia is a way to highlight the visions of different territorial scales and self-representations they carry.

\section{Symbolic crusades?}

In order to de-specify collective action for regional and minority languages, it is useful to perceive them as an ordinary kind of social movement. French political scientist Lilian Mathieu distinguishes symbolic crusades from other forms of mobilization by the will of their members not only to protect ethic or cultural norms, but also, and maybe more importantly, to impose them on their social environment (Mathieu, 2005), which was the case of the "assimilative" and "coercive" reforms (Gusfield, 1963, 1986) implemented by temperance campaigners, including the adoption of the Eighteenth Amendment. As it turns out from my research, however, none of the four movements displays such aggressive characteristics, nor has much moral influence on political institutions. It is therefore complicated to qualify linguistic collective action in Brittany and Lusatia as "symbolic crusades", although linguistic minorities still try to transmit their languages to other people, be it children or adults, and that is what I am going to study here.

What will draw my attention here is not the militant connotation of Gusfield's terminology, which attributes a certain position of power to moral entrepreneurs. Rather, I intend to propose a softened and widened variant of the definition of symbolic crusades, approached here as an ideal type. To this end, I will study the modalities of language transmission in the four cases, and try to show how the simple fact of transmitting an endangered language is already a commitment to a given speech community.

First, minority language campaigners do not share the same vision of the importance of transmitting the language to out-group members. In Lusatia, the transmission of Sorbian languages, particularly Upper Sorbian, is often performed in families, with Upper Sorbian parents raising their children in Upper Sorbian. Therefore, the immersion is almost complete, and children learn Upper Sorbian as their mother tongue. Upper Sorbian parents would often report to me during interviews or conversations some episodes when their children discovered that people in big cities of Saxony or Brandenburg do not speak Sorbian, and that they were shocked by this fact. Therefore, walking the streets of Leipzig or Berlin speaking Upper (or sometimes Lower) Sorbian with one's 
children is already expressive and implies a desire for recognition (Honneth, 1992); it also involves the risk of being glanced at with surprise or suspicion by non-Sorbian speakers. In Lusatia, where far-right parties reach their top election results in Germany, it takes courage and commitment to the linguistic cause and to the community to affirm oneself as a Sorb in the public sphere, given that numerous far-right activists will greet Sorbs with the Nazi salute ${ }^{15}$ or worse.

Second, even if family transmission of Upper Sorbian has not been interrupted - contrary to the transmission of Breton and Gallo in Brittany - the teaching of Upper Sorbian at schools hardly produces newspeakers, because of persistent divisions between children from Sorbian families and the others, insufficient school material in Upper Sorbian, and a negative social image associated with the language (Dołowy-Rybińska \& Ratajczak, 2019). Lower Sorbian schools seem to face similar problems, as an important member of the Witaj project confirms: "Witaj suggests immersion, but it isn't applied in schools"."16

Moreover, family transmission is very weak in Lower Lusatia. Some Lower Sorbian activists encountered in the course of fieldwork came from other Slavic countries and had learnt the language during their secondary socialization process. They are now very active in the revitalization process, although they are not numerous. In some other cases, people fighting for the sustainability of Lower Sorbian schools did not have the command of the language themselves. In this case, the whole process relies upon school, because familial transmission is impossible. A low family transmission in Lusatia is hardly counterbalanced by the efficiency of Witaj classes, whereas Diwan schools have been seen as a legitimate substitute of family immersion in Brittany.

Third, the creation of these Breton immersion schools in 1977 was directly inspired by the rebellious spirit of the 1970s and the emergence of a new political and cultural Breton movement (Kernalegenn, 2005; Nicolas, 2012). Considering that native Breton speakers were getting older, and that there was a break of intergenerational transmission due to the social disqualification of the language, activists took up the challenge of transmitting it through schools, where most of the pupils had not been raised in Breton. Every Breton interviewee agreed that Diwan schools were the very core of the revitalization process. To them, it was the only initiative that could really save the language.

\footnotetext{
${ }^{15}$ This was reported to me in an interview with a young Lower Sorbian cultural activist, who is also a German teacher for refugees; the interview was conducted on 12 May 2017.

16 "Witaj suggeriert Immersion, und die wird in der Schulen nicht praktiziert".
} 
In Lusatia, the opinions on Witaj (welcome) schools are divided. In addition to their unsatisfactory results in terms of teaching outcomes they seem to bring at the moment, given a report conducted in 2018 (Abschlussbericht, 2018), they have been met with scepticism since their very beginning. ${ }^{17}$ On the other hand, the creation of Diwan (seed) schools in 1977 was supported by the majority of the Breton movement. Although the rules of linguistic transmission are different in the cases of Breton, Upper Sorbian, Lower Sorbian and Gallo, all linguistic movements are willing to spread the language they consider endangered. But here, the parallel with symbolic crusades encounters an important limit. Indeed, temperance activists studied by Gusfield came from former dominant classes of American society, who began to fear the increasing number of workers and immigrants with different cultural codes. It is difficult to objectify this feeling of fear, since it is subjective per se (Gusfield, 1963, 1986, p. 15). In the four cases considered here, there are elements which can precisely confirm the decrease of regional and minority speakers in Brittany and Lusatia. Moreover, the linguistic activists do not fear the simple idea of decline, since they have been declining for years, or even centuries: they simply want to stop the process of further decline.

There is in each of these movements a wish to access politics in order to achieve instrumental goals. Indeed, governments affect the distribution of values through symbolic acts, as well as through the force of instrumental ones. With symbolic gestures, political leaders show deference or despise to a given status group (Gusfield, 1986, p. 11). The struggle to control the symbolic actions of governments is therefore as real as the struggle to control its instrumental policies. In fact, collective action in favour of minority languages does have political interests that can be analysed through the pattern of status politics.

Before the introduction of the notion of status politics, American political science would analyse mobilizations using two models (Gusfield, 1963, 1986, pp. 177-178). The first one was the model of class politics, drawing on economic action and reflecting the struggle for economic interests. The other model was called psychological expressivism and described politics as an arena onto which irrational impulses were projected. This classification had the disadvantage of dividing movements into rational and irrational ones, instead of considering them as a mix of class issues, expression issues and status issues. For instance, there

\footnotetext{
${ }^{17}$ Interview with the pioneer of Witaj schools, conducted in his house in Panschwitz-Kuckau (Saxony) on 6 February 2017.
} 
is a connection between class and status in the long run, and the sake of expression also matters in cultural demands. Therefore, considering political action as a mix of class, status and expression issues sheds a new light on the making of political processes concerning regional and minority languages in Brittany and Lusatia.

In the course of my fieldwork in Upper Brittany, I regularly heard Gallo activists repeat that Gallo was more despised than Breton because it was the language of the poor and the peasants, whereas Breton was spoken by the urban intelligentsia (which is only partially true). ${ }^{18}$ For these activists, fighting for the Gallo language was therefore a way to upgrade the social worth of it, but also of a whole social class. Linguistic claims, then, were embedded in class issues.

Furthermore, collective linguistic action is not devoid of expressive issues. It is enriching to look at Easter celebrations in Upper Lusatia, with their ritualized processions of Jatšowne rejtowanje (Easter Ride) - Sorbian men in suits riding on horseback from town to town and singing traditional Upper Sorbian Christian tunes - to understand that there certainly is some expression for its own sake, that is to say without immediate political demands, in the Upper Sorbian movement. Although the Jatšowne rejtowanje cannot be considered a social movement per se, their day-long parade in the Easter Sorbian cold has to be seen as part of a broader cultural repertoire. One way to de-naturalize it is to look in parallel at the Breton Redadeg (race), a running event covering the whole Breton territory, where people are encouraged to run to the sound of Breton tunes (Chauffin, 2015, p. 200). The idea of drawing a parallel between the two events came to me when observing the arrival of Jatšowne rejtowanje horsemen and of Redadeg runners in 2018. In both cases, the groups carried Breton or Sorbian flags, sang proudly, and wore specific clothes (traditional male ones for the Jatšowne rejtowanje, T-shirts with the Redadeg symbol for the Breton event). In my opinion, these similarities underline the expressive part of language movements.

Reading linguistic mobilizations in the light of combined class, status and expression processes enabled me to see how these mobilizations can find their way into politics. Indeed, when it comes to their transition to the political area, political connotations of symbolic crusades are hardly stable at all, and can be supported both by right-wing and

\footnotetext{
${ }^{18}$ I assert this because it seemed to me that some Gallo activists perceived all Breton activists as people from the urban upper middle class. This does not correspond to my fieldwork research findings, which show that some Breton language campaigners come from lower social classes and live in rural towns.
} 
left-wing organisations alike (Gusfield, 1963, 1986, p. 185). My research occasioned meeting activists with left-wing or right-wing ideals standing up for regional and minority speech communities. However, I did not talk politics (Gamson, 1992) with all of them; a significant proportion of Gallo and Sorbian interviewees would say in effect that they were neither concerned about, nor interested in politics. ${ }^{19}$

Even in Brittany, where the number of minority language speakers is about ten times higher than in Lusatia, the significance of ethno-regionalist organizations in elections remains low, and they have difficulties to make room for the two languages in their programmes (often giving priority to Breton). Nevertheless, these political parties are socially accepted, have a long tradition of mobilization, and are considered a central part of the Breton movement.

It is very different in Lusatia, where the only Sorbian political party, the Lausitzer Allianz (Lusatian Alliance), only counts a few members. Yet Upper and Lower Sorbs have a political representation through the umbrella association Domowina. Its president, who is also a member of the CDU party, is a legitimate discussion partner for local and national representatives when it comes to making decisions concerning Sorbian interests. These interests are discussed during political occasions like sessions of the Sorbenrat (Sorbian Council), held at the Brandenburg Landtag or its Saxon equivalent. Quite a similar institution, though only consultative, was established in 1977 in Brittany: the Brittany Cultural Council was created on the wave of decentralization symbolized by the signing of the Charte Culturelle (Cultural Charter) by the French government. Over time, the Cultural Council slowly began to include Gallo issues in the field of its activity. Nevertheless, the effective political weight of Upper Sorbian, Lower Sorbian, Breton and Gallo status movements is also influenced by the amount of public funding. Indeed, around 18.6 million euros each year is allocated to the Stiftung für das Sorbische Volk (Foundation for the Sorbian People), whereas the Regional Council of Brittany only spends 6 million euros on the Breton language, and 300,000 euros on Gallo. It is fair to add that the funding for the Stiftung für das Sorbische Volk serves both the Sorbian language and cultural life, which may also be one of the reasons why Sorbs do not separate language and culture as easily as Breton or even Gallo speakers.

\footnotetext{
${ }^{19}$ For example, a Gallo activist deplored the fact that Gallo circles were increasingly more invested by politics. An Upper Sorbian interviewee laughed at me when asked to talk about his "political life", although he was the founder of an association demanding a Sorbian parliament. It is indeed a classical phenomenon which occurs in social movements: beyond the will to gather people from different political backgrounds, activists often perceive the political arena as a distant and artificial one, whereas their specific field of activism seems to be "close to home" (Eliasoph, 1998, p. 86).
} 


\section{Conclusions}

On the whole, minority language mobilizations in Lusatia and Brittany can be described as symbolic crusades with reference to more than one aspect, provided that we take certain methodological precautions into account. Considering Gusfield's symbolic crusades as an ideal type helped me to include in my analysis structural elements of linguistic mobilizations which exceeded language issues. Although the category of status politics remains highly subjective, it is still a relevant label to take into account the importance of styles of life, social classes and cultural issues for minority language movements, standing guard against their essentialization. To extend this analysis, other indicators such as social profiles of the activists, which I did not discuss here, could be taken into account.

What matters most in this study is that social status movements in Brittany and Lusatia can be analysed without separating cultural practices from collective repertoires of contention (Tilly, 1984). Putting the focus of the symbolic stakes driven by such movements within the general space of social movements (Mathieu, 2002, 2005) could thus be a stimulating way to understand interdependencies between social status issues, social movements and the specificity of spatially and culturally situated phenomena such as regional and minority languages.

\section{Bibliography}

Abschlussbericht über die externe Evaluation von Sorbisch/Wendisch-Angeboten der Primarstufe im Land Brandenburg. (2018). Universität Leipzig. Retrieved September 27, 2019, from https://sorb .philol.uni-leipzig.de/download/0/0/1866108619/8f63e564909d1f5814da9f0cbef8fd932aabe2d1 /fileadmin/sorb.philol.uni-leipzig.de/uploads/dokumente/2018/Abschlussbericht.Evaluation .LISUM.pdf?fbclid=IwAR3X4HWyjH32zmYZWa-5e0S7LKG9vM7XYrA9WQ25v32u1r26yG1N89b0DfcU Broqua, C. (2015, November 24). L'homosexualité au Sénégal ou la construction d'un problème public international. Speech given at the conference Croisades privées et problèmes publics. L'héritage sociologique de Joseph Gusfield, Paris, EHESS.

Chauffin, F. (2015). Diwan, pédagogie et créativité: approche critique des relations entre pédagogie, créativité et revitalisation de la langue bretonne dans les écoles associatives immersives Diwan (PhD thesis under the direction of Professor R. Le Coadic). University of Rennes 2.

Costa, J. (2013). Enjeux sociaux de la revitalisation linguistique: Introduction. Langage et société, 2013(3(145)), 7-14. https://doi.org/10.3917/ls.145.0007

Dołowy-Rybińska, N. (2016a). Language attitudes and community engagement: Diwan the Breton immersion high school through the eyes of its pupils. Journal of Language, Identity \& Education, 15(5), 280-292. https://doi.org/10.1080/15348458.2016.1213134 
Dołowy-Rybińska, N. (2016b). Becoming an activist: A self-representation of young European campaigners for minority languages. In J. Olko, T. Wicherkiewicz, \& R. Borges (Eds.), Integral strategies for language revitalisation (pp.405-436). Warszawa: Wydział "Artes Liberales" Uniwersytetu Warszawskiego.

Dołowy-Rybińska, N., \& Ratajczak, C. (2019). Languages and cultures in contact: The place of new speakers in the education system in Upper Lusatia. Cognitive Studies | Études cognitives, 2019(19). https://doi.org/10.11649/cs.1901

Eliasoph, N. (1998). Avoiding politics: How Americans produce apathy in everyday life. Cambridge: Cambridge University Press.

Gamson, W. (1992). Talking politics. Cambridge: Cambridge University Press.

Gauchet, M. (1985). Le désenchantement du monde. Une histoire politique de la religion. Paris: Gallimard.

Gusfield, C. (1963). Symbolic crusade: Status politics and the American temperance movement. Urbana: University of Illinois Press.

Gusfield, C. (1986). Symbolic crusade: Status politics and the American temperance movement (2nd ed.). Urbana: University of Illinois Press.

Honneth, A. (1992). The struggle for recognition: The moral grammar of social conflicts. Cambridge: Polity Press.

Kernalegenn, T. (2005). Drapeaux rouges et Gwenn-ha-du, I'Extrême-Gauche et la Bretagne dans les années 1970. Rennes: Apogée.

Kernalegenn, T. (2006). Luttes écologistes dans le Finistère: Les chemins bretons de l'écologie 1967-1981. Fouesnant: Yoran Embanner.

Kernalegenn, T. (2018). La recomposition du mouvement breton au tournant des années 1980. In G. Richard \& S. Ollitrault (Eds.), Les Années Mitterrand 1984-1988. L'Alternance et la Cohabitation vues des Régions. Rennes: Presses Universitaires de Rennes.

Le Bart, C. (2008). L'individualisation. Paris: Presses de Sciences Po.

Lipset, S. M., \& Rokkan, S. (1967). Party systems and voter alignments: Cross-national perspectives. London: Collier-Macmillan.

Mathieu, L. (2002), Rapport au politique, dimensions cognitives et perspectives pragmatiques dans l'analyse des mouvements sociaux. Revue Française de Science Politique, 1, 75-100. https:// doi.org/10.3406/rfsp.2002.403696

Mathieu, L. (2005). Repères pour une sociologie des croisades morales. Déviance et Société, 29(1), 3-12. https://doi.org/10.3917/ds.291.0003

Neveu, É. (2011). Sociologie des mouvements sociaux. Paris: La Découverte.

Nicolas, M. (2012). Breizh. La Bretagne revendiquée. Morlaix: Skol Vreizh.

Tilly, C. (1984, October). Les origines du répertoire d'action collective contemporaine en France et en Grande-Bretagne. Vingtième Siècle, revue d'histoire, 1984(4), 89-108. https://doi.org/10.3406 /xxs.1984.1719 
TMO Régions. (2018). Les langues de Bretagne: Enquête sociolinguistique. Retrieved September 27, 2019, from https://www.bretagne.bzh/upload/docs/application/pdf/2018-10 /etude_languesbretagne.pdf

Touraine, A. (1978). La voix et le regard. Paris: Editions du Seuil.

Traïni, C. (2011). La cause animale: Essai de sociologie historique (1820-1980). Paris: Presses Universitaires de France. https://doi.org/10.3917/puf.trai.2011.01

Urry, J. (2005). Sociétés (N. Burch, Trans.). In J. Urry, Sociologie des mobilités: Une nouvelle frontière pour la sociologie? (pp. 15-34). Paris: Armand Colin.

Weber, M. (1959). Le savant et le politique. Paris: Plon.

\section{Krucjaty symboliczne na Łużycach i w Bretanii? Próba spojrzenia na aktywizm mniejszości językowych poprzez analizę polityki statusu}

\section{Abstrakt}

Artykuł proponuje spojrzenie na mobilizację użytkowników regionalnych języków mniejszościowych na Łużycach i w Bretanii z perspektywy polityki statusu. W ponowoczesnym kontekście, w którym tradycyjne wspólnoty komunikacyjne zostały rozbite przez wzrost mobilności terytorialnej i społecznej, używanie języka mniejszościowego wydaje się kwestią jednostkowego wyboru, realizowanego poprzez osobiste zaangażowanie i aktywizm. Przyjmując założenie, że języki stanowią element ekonomii lingwistycznej, kształtowanej przez konflikty władzy i potrzebę klasyfikacji, artykuł traktuje promowanie języków regionalnych i mniejszościowych jako walkę o akceptację konkretnych kultur i stylów życia oraz o prestiż społeczny. Korzystając z narzędzi socjologii politycznej, autorka stawia sobie za cel zbadanie działań na rzecz języków górnołużyckiego, dolnołużyckiego, bretońskiego i gallo jako działalności symbolicznej, mającej prowadzić do zmian w dystrybucji prestiżu społecznego na Łużycach i w Bretanii, a zatem wykraczającej poza kwestie czysto językowe. Obecnie działacze na rzecz języków mniejszościowych na Łużycach i w Bretanii biorą udział w „ruchu rewitalizacyjnym”, który przedstawia również własną wizję świata społecznego. Opierając się na częściowo ustrukturyzowanych wywiadach z aktywistami językowymi oraz na obserwacji uczestniczącej, autorka próbuje określić, do jakiego stopnia mobilizacja językowa może być uznana za „krucjatę symboliczną" i w jaki sposób ta wywodząca się z socjologii koncepcja może być przydatna dla zrozumienia mechanizmów funkcjonujących w szerszym kontekście działań zbiorowych o charakterze językowym.

\section{Słowa kluczowe:}

działanie zbiorowe; języki regionalne; mniejszościowe wspólnoty językowe; języki mniejszościowe; polityka porównawcza; krucjaty symboliczne; Łużyce; Bretania 


\section{Symbolic crusades in Lusatia and Brittany? An analysis of minority language movements from the perspective of status politics}

\section{Abstract}

This paper proposes to analyse mobilizations for regional minority languages in Lusatia and Brittany from the perspective of "status politics". In a post-modern context, where traditional speech communities are fragmented by territorial and social mobility, speaking a minority language seems to be a matter of personal choice, structured through engagement and activism. Assuming that languages are part of a linguistic economy shaped by power conflicts and struggle for classifications, this article approaches the promotion of regional and minority languages as a struggle for social recognition of particular cultures, styles of life and collective prestige. By using the tools of political sociology, our ambition is to examine actions for Upper and Lower Sorbian, Breton and Gallo as symbolic ones, aiming at influencing the distribution of social prestige in Lusatia and Brittany, thus exceeding mere language issues. Today, campaigners for minority languages of Lusatia and Brittany participate in "revitalization movements" which also assert visions of the social world. Drawing on semi-structured interviews with language activists and on participatory observations, the idea is to consider to what extent linguistic mobilizations can be qualified as "symbolic crusades", and in what ways this sociological notion could be useful to understand the mechanisms at work in linguistic collective action in general.

\section{Keywords:}

collective action; regional languages; minority speech communities; minority languages; comparative politics; symbolic crusades; Lusatia; Brittany

\section{Citation:}

Toutous, J. (2019). Symbolic crusades in Lusatia and Brittany? An analysis of minority language movements from the perspective of status politics. Adeptus, 2019(14). https://doi.org/10.11649/a.1942 